\title{
The Importance Of The Control Environment: Expense Account Fraud At Blue Grass Airport
}

Thomas G. Noland, University of South Alabama, USA Eddie Metrejean, Georgia Southern University, USA

\begin{abstract}
COSO's Internal Control Framework discusses the components of internal control and how the control environment is the most important component. This paper analyzes how a non-existent control environment led to a massive expense account fraud at a regional airport. This fraud eventually led to the resignation and prosecution of the airport's top four executives. The paper discusses the findings of the State Auditor's investigation and outlines the red flags that should have been obvious to the external auditors. The paper concludes by discussing the changes made to the airport's internal controls in the aftermath of the fraud.
\end{abstract}

Keywords: Analytical Procedures; Control Environment; Control Procedures; Expense Account Fraud

\section{INTRODUCTION}

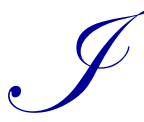

n June of 2010, Michael Gobb, the former Executive Director (CEO) of Blue Grass Airport (airport) in Lexington, Kentucky, pleaded guilty to two counts of theft by deception after being caught charging personal items to his airport credit card. Gobb received a five-year prison sentence, but the judge in the case order probation instead of prison and required Gobb to undergo random drug and alcohol testing and complete 500 hours of community service (Hewlett, 2010b). Gobb also repaid more than $\$ 55,000$ in restitution.

Gobb was not the only executive of the airport to misuse the airport's credit cards. By the time the investigation was complete, three other executives (Director of Administration and Finance, Director of Operations, and the Director of Planning and Development) had also pleaded guilty to various charges of theft by deception for misuse of their airport credit cards. A report by the Auditor of Public Accounts of the Commonwealth of Kentucky (State Auditor) found over \$500,000 in undocumented or questionable expenses at the airport from January 1, 2006 through December 31, 2008.

While most expense account frauds are not perpetrated by an entity's top executives, the 2010 Report to the Nations on Occupational Fraud and Abuse sponsored by the Association of Certified Fraud Examiners (ACFE) reports that the median duration of expense reimbursement fraud is 24 months in length and involves a median loss of $\$ 33,000$. The ACFE describes expense reimbursement fraud as "Any scheme in which a person makes a claim for reimbursement of fictitious or inflated business expenses" (ACFE, 2010, p. 15). The ACFE study also found that expense reimbursement schemes were $15.1 \%$ of all fraud cases that involved asset misappropriations (ACFE, 2010).

This paper summarizes the Blue Grass Airport fraud scheme and examines expenditures made by the perpetrators over a three-year period. The paper discusses the Committee of Sponsoring Organization's (COSO) internal control framework and summarizes the penalties, or lack thereof, levied on the perpetrators of the expense reimbursement fraud. The paper concludes by making some simple recommendations to improve an entity's internal controls. 


\section{AIRPORT STRUCTURE}

The airport is a public, not-for-profit corporation run by a board appointed by Lexington's mayor and confirmed by the Urban County Council. The board consists of 10 members who each serve four-year terms and may be reappointed for one additional four-year term. The board members are volunteers and receive no salaries. Airport revenue for FY 2008 was $\$ 18.5$ million and came from both private and public sources, including the Federal Aviation Administration, airlines and general aviation operations, rental car companies, parking lots, and food and merchandise vendors (Commonwealth of Kentucky, 2009).

The Board was structured into four committees: Finance, General Development and Operations, Internal Affairs, and General Aviation. The Finance Committee was responsible for the oversight and review of financial matters, such as budget requests and monthly financial reports. The entire Board was responsible for oversight of the overall operations and planning of the airport, but actual day-to-day operations were managed by the Executive Director.

\section{COSO'S INTERNAL CONTROL FRAMEWORK}

The expense account fraud at the airport was perpetrated because of a non-existent control environment and a break-down in corporate governance within the airport management structure. Internal Control - Integrated Framework, published by The Committee of Sponsoring Organizations of the Treadway Commission, describes five components of internal control:

$\begin{array}{ll}- & \text { Control Environment } \\ - & \text { Risk Assessment } \\ - & \text { Control Activities } \\ - & \text { Information and Communication } \\ \text { - } & \text { Monitoring }\end{array}$

The control environment serves as the umbrella for the other four categories. The control environment is made up of the actions and policies that reflect the attitudes of top management and the directors of the entity (COSO, 1992). Without an effective control environment, the other four components of internal controls will not likely result in effective controls. Critical to the control environment are the entity's ethical and behavioral standards and how they are communicated and enforced within the organization. Unless top management believes that controls and ethical standards are important, other employees are not likely to be concerned with either ethical business practices or internal controls.

Another key part of the control environment is an effective board of directors (COSO, 1992). An engaged board of directors is essential for effective corporate governance because the board had the responsibility to ensure management implements proper internal controls and financial reporting processes. The board should have an audit committee that is independent from management; i.e., composed of directors who are not employees of the organization and is responsible for overseeing financial reporting and the assessment of internal controls.

Risk assessment involves examining areas that pose a risk to the organization, and determining what policies and procedures could be implemented to mitigate those risks (COSO, 1992). Without management assessing the risks that an organization faces, putting the proper controls in place would be almost impossible.

Control activities are the policies and procedures that management puts in place to ensure that its directives are carried out (COSO, 1992). These policies and procedures are what most people think about when they hear the term internal controls. Without the proper control activities in place, errors and irregularities will inevitably occur. Examples of these control activities are separation of duties, reconciliations, and security of assets, among others (COSO, 1992).

While the other components of internal control are certainly important, this paper focuses on the control environment and control activities because they are the most relevant to this case. 


\section{RED FLAGS AT THE AIRPORT}

Statements on Auditing Standards (SAS) No. 99: Consideration of Fraud in a Financial Statement Audit states that auditors must remain aware that certain indicators of fraud, or red flags, may be present in an organization's accounting records. These red flags include unsupported or unauthorized balances or documents, missing documents, significant unexplained items on documents, and inability to produce documents in a timely manner, among others (AICPA, 2002). In the case of the airport, multiple red flags existed that should have been detected and investigated.

The airport regularly overspent its budget for travel and training for staff. In FY 2007, the airport budgeted approximately $\$ 120,000$ but spent over $\$ 219,000$. In a 27 - month period (from January 2006 through March 2008), Gobb spent over $\$ 200,000$ on travel and other expenses (Hewlett, 2008a). Gobb stayed in style at the Waldorf Astoria Hotel in St. Petersburg, Russia, the Hay-Adams in Washington, D.C., the Ritz Carlton in Henderson, NV, and the Bellagio in Las Vegas. Gobb's travel expenses were in addition to his salary of $\$ 220,000$, unlimited use of an airport Ford Expedition to include gas reimbursement, home internet and cell phone service, and payment of club and association membership. These expenses totaled over \$36,500 in 2008 alone. In the 36-month period for which expenses were reviewed by the State Auditor, the Board Chair, who was responsible for approving Gobb's expenses, approved only three of the monthly expense reports. The Board's minutes did not discuss approval for spending on executive travel, marketing expenditures or events hosted by the airport. It appears that Board oversight was not an important part of the airport's internal controls.

Several airport employees were given credit cards issued to the airport, but no policy for limiting expenditures or review of the credit card purchases existed. Access to a credit card without oversight is an area ripe for fraud. Employees may end up using the organization's credit cards as their own personal credit cards, as was the situation with the airport.

Blue Grass Airport did have its financial statements audited by an external auditor, but had few fraud prevention controls in place. The airport did not employ an internal auditor and had used the same accounting firm, Lexington-based Potter and Co., for 20 years. Potter and Co. was paid \$327, 621 for their services for the last three audits completed. Kentucky State Auditor, Crit Luallen, stated, "Clearly, some red flags should have been raised in the auditing process." (Hewlett and Alessi, 2009)

For example, at the time of the audits, auditors were required by SAS No. 56: Analytical Procedures to perform analytical procedures on the entity's financial data. SAS No. 56 requires analytical procedures to be performed during both the planning and final review stages of an audit and as an optional source of evidence during the detailed testing phase of an audit. Paragraph five of SAS No. 56 states, in part, that analytical procedures involve comparisons of recorded amounts, or ratios developed from recorded amounts, to expectations developed by the auditor. The auditor develops such expectations by identifying and using plausible relationships that are reasonably expected to exist based on the auditor's understanding of the client and of the industry in which the client operates. Following are examples of sources of information for developing expectations:

1. Financial information for comparable prior period(s) giving consideration to known changes

2. Anticipated results - for example, budgets, or forecasts including extrapolations from interim or annual data (AICPA, 1988)

As stated above, the airport regularly overspent its budget for travel and training for staff. If the external auditors had compared actual travel and training expenses to budgeted amounts, they should have detected the large differences and subsequently detected the fraudulent reimbursement to the executive officers. It is possible that the auditors did question these significant differences from budgeted to actual amounts but allowed management to explain away the differences. Generally, oral or written representations from management are not considered to be very reliable evidence without additional corroboration. The auditor should obtain more reliable forms of evidence to support management's oral and written assertions. While the auditors may have obtained some evidence, the auditors do not appear to have investigated the variances or they would have questioned the propriety of the 
expenditures. Table 1 shows that actual expenses spent on training and travel significantly exceeded the budget for all three years reviewed by the state auditor.

Table 1: Comparison of Airport Training and Travel Budget to Actual Expenditures

\begin{tabular}{|c|c|c|c|}
\hline Year & Budget & Actual & \% of Budget \\
\hline 2006 & $\$ 90,000$ & $\$ 165,671$ & $184 \%$ \\
\hline 2007 & $\$ 120,000$ & $\$ 219,140$ & $183 \%$ \\
\hline 2008 & $\$ 150,000$ & $\$ 198,754$ & $133 \%$ \\
\hline
\end{tabular}

\section{STATE AUDITOR'S FINDINGS}

After the fraudulent spending came to light, the State Auditor conducted an examination of selected financial transactions. The State Auditor detailed more than $\$ 500,000$ in undocumented and questionable expenses incurred by airport officials. State Auditor Crit Luallen stated, "I don't think we have seen an audit where so many different individuals in the management of a public agency abused the trust with such arrogance and a lack of ethical standards." (Hewlett and Alessi, 2009)

Table 2 shows the state's auditors found that over a three-year period, 92\% of Executive Director Gobb's total expenses had no documentation to support reimbursement. The summary shows that only a small portion of Gobb's purchases were legitimate and supported by adequate documentation, which, as stated above, should have been a red flag to auditors. In addition to the expenditures charged directly to Gobb's credit card, Operations Director John Coon told auditors that Gobb would ask for his credit card number and expiration date each time Coon was issued a new card. Director of Administration and Finance John Rhodes stated that when traveling, Gobb would often charge meals and entertainment expenses to other executives' rooms instead of his own (Hewlett and Alessi, 2009). The auditors found that Wii games, Eddie Bauer clothing, and DVDs were purchased by Gobb and charged to the credit cards of other cardholders. Table 3 shows examples of these inappropriate or undocumented expenditures incurred by Gobb.

Table 2: Summary Analysis - Executive Director Michael Gobb's Credit Card Transactions

\begin{tabular}{|c|c|c|c|c|c|}
\hline Year & $\begin{array}{c}\text { Total Credit Card } \\
\text { Expenditures }\end{array}$ & $\begin{array}{c}\text { Inadequate } \\
\text { Documentation or } \\
\text { Questionable Business } \\
\text { Purpose }\end{array}$ & $\begin{array}{c}\text { Percent of Credit } \\
\text { Card Expenditures }\end{array}$ & $\begin{array}{c}\text { No Supporting } \\
\text { Documentation }\end{array}$ & $\begin{array}{c}\text { Percent of Credit } \\
\text { Card Expenditures }\end{array}$ \\
\hline 2006 & $\$ 52,839$ & $\$ 3,518$ & $6.7 \%$ & $\$ 49,044$ & $92.8 \%$ \\
\hline 2007 & $\$ 64,515$ & $\$ 3,150$ & $4.9 \%$ & $\$ 60,400$ & $93.6 \%$ \\
\hline 2008 & $\$ 41,029$ & $\$ 372$ & $0.9 \%$ & $\$ 36,278$ & $88.4 \%$ \\
\hline Total & $\$ 158,383$ & $\$ 7,040$ & $4.4 \%$ & $\$ 145,722$ & $92.0 \%$ \\
\hline
\end{tabular}

Table 3: Examples of Unsupported Credit Card Transactions by Executive Director Michael Gobb (No Documentation was provided for Reimbursement)

\begin{tabular}{|l|c|}
\hline \multicolumn{1}{|c|}{ Vendor Name } & Transaction Amount \\
\hline Hobbytown USA & $\$ 4,141$ \\
\hline The Copthorne Tara & $\$ 1,364$ \\
\hline Liquor Barn & $\$ 1,331$ \\
\hline Michaels & $\$ 1,084$ \\
\hline Hobbytown USA & $\$ 1,007$ \\
\hline Lowes & $\$ 1,004$ \\
\hline The Keeneland Shop - Racetrack & $\$ 970$ \\
\hline Waipip Valley Artworks & $\$ 927$ \\
\hline Liquor Barn & $\$ 860$ \\
\hline Longboat Key Club & $\$ 843$ \\
\hline Stubhub Tickets & $\$ 795$ \\
\hline
\end{tabular}

The ACFE reports that nearly $12 \%$ of fraud perpetrators have addiction problems (ACFE, 2010). During the course of the investigation, the auditors found that Gobb routinely made purchases from liquor stores on the airport's credit card. Gobb later admitted to prescription drug abuse and problems with alcohol. 
The State Auditor further found that seven airport employees had airport credit cards, but there was no policy related to the use or review of credit card statements. In addition, because there was no review process, duplicate payments were sometimes made to employees. As detailed in Tables 4 through 10, the other six employees with airport credit cards used them as if they were their personal credit cards. Some of the more unusual and questionable charges include purchases of shotguns and ammunition, cigar humidifiers, Hannah Montana concert tickets, Wii systems, $\$ 700$ bottles of champagne, Godiva chocolates, concert and ballgame tickets, and numerous golf-related charges. When interviewed by the State Auditor's office, the Director of Administration and Finance, John Rhodes, stated that he could not recall anyone ever being denied payments related to purchases with airport funds (Commonwealth of Kentucky Auditor of Public Accounts, 2009, p. 42). These purchases ranged from $36.3 \%$ to $48.6 \%$ questionable expenditures and $3.5 \%$ to $31.1 \%$ expenditures with no supporting documentation. While these purchases were not as egregious as Gobb's expenditures, these executives were nonetheless as guilty as Gobb.

Table 4: Examples of Unsupported or Questionable Credit Card Transactions Director of Administration and Finance John Rhodes

\begin{tabular}{|l|c|}
\hline \multicolumn{1}{|c|}{ Vendor Name } & Transaction Amount \\
\hline TIVO Service - 2 Units & $\$ 3,827$ \\
\hline Amazon.Com - Canon Telephoto Lens & $\$ 1,692$ \\
\hline Hyatt Hotels - Itemized Bottle of Champagne \$700 & $\$ 1,049$ \\
\hline Hamgo Electronics Supplier - No documentation & $\$ 748$ \\
\hline Pure Las Vegas - Champagne & $\$ 702$ \\
\hline Walmart.com - Wii and Accessories & $\$ 663$ \\
\hline The GPS Store- Handheld GPS and items for Executive Director & $\$ 649$ \\
\hline US Sedan Service - Limo Services & $\$ 521$ \\
Two Dates & $\$ 458$ \\
\hline Jones Byrd Clubhouse - Golf & $\$ 174$ \\
Three Different Dates & $\$ 46$ \\
\hline Scott Davenport - Golf Clothing \& Supplies & $\$ 335$ \\
\hline Poipu Bay Golf Course - Golf Shoes, Glove Etc. & $\$ 292$ \\
\hline
\end{tabular}

Table 5: Summary Analysis - Director of Administration and Finance John Rhodes's Credit Card Transactions

\begin{tabular}{|c|c|c|c|c|c|}
\hline Year & $\begin{array}{c}\text { Total Credit Card } \\
\text { Expenditures }\end{array}$ & $\begin{array}{c}\text { Inadequate } \\
\text { Documentation or } \\
\text { Questionable Business } \\
\text { Purpose }\end{array}$ & $\begin{array}{c}\text { Percent of Credit } \\
\text { Card Expenditures }\end{array}$ & $\begin{array}{c}\text { No Supporting } \\
\text { Documentation }\end{array}$ & $\begin{array}{c}\text { Percent of Credit } \\
\text { Card Expenditures }\end{array}$ \\
\hline 2006 & $\$ 36,161$ & $\$ 12,587$ & $34.8 \%$ & $\$ 9,918$ & $27.4 \%$ \\
\hline 2007 & $\$ 31,390$ & $\$ 10,198$ & $32.5 \%$ & $\$ 12,781$ & $40.7 \%$ \\
\hline 2008 & $\$ 23,920$ & $\$ 10,410$ & $43.5 \%$ & $\$ 5,781$ & $24.2 \%$ \\
\hline Total & $\$ 91,471$ & $\$ 33,195$ & $36.3 \%$ & $\$ 28,480$ & $31.1 \%$ \\
\hline
\end{tabular}

Table 6: Examples of Unsupported or Questionable Credit Card Transactions - Operations Director John Coon

\begin{tabular}{|l|c|}
\hline \multicolumn{1}{|c|}{ Vendor Name } & Transaction Amount \\
\hline Dick's Sporting Good- Purchase 3 Shotguns and a Rifle plus accessories & $\$ 1,900$ \\
\hline Dahana Ranch - Horseback Riding & $\$ 1,449$ \\
\hline Eddie Bauer - Clothes & $\$ 1,046$ \\
\hline Best Buy - Bose Headphones/MP3 & $\$ 739$ \\
\hline Barry's Ticket Service - 4 tickets to Baltimore Orioles and Arizona Diamondbacks Game & $\$ 697$ \\
\hline Golf Galaxy - Golf Equipment & $\$ 676$ \\
\hline Discovery Channel - DVDs & $\$ 598$ \\
\hline Best Buy - Tom Tom Navigation System & $\$ 529$ \\
\hline Liquor Barn - Unknown & $\$ 477$ \\
\hline The Batter Box - 4 Polo Shirts and 8 Baseball Caps & $\$ 376$ \\
\hline Liquor Barn- Cigars & $\$ 240$ \\
\hline Nevada Bob's Golf - Shoes \& Umbrella & $\$ 204$ \\
\hline
\end{tabular}


Table 7: Summary Analysis - Operations Director John Coon's Credit Card Transactions

\begin{tabular}{|c|c|c|c|c|c|}
\hline Year & $\begin{array}{c}\text { Total Credit Card } \\
\text { Expenditures }\end{array}$ & $\begin{array}{c}\text { Inadequate } \\
\text { Documentation or } \\
\text { Questionable Business } \\
\text { Purpose }\end{array}$ & $\begin{array}{c}\text { Percent of Credit } \\
\text { Card Expenditures }\end{array}$ & $\begin{array}{c}\text { No Supporting } \\
\text { Documentation }\end{array}$ & $\begin{array}{c}\text { Percent of Credit } \\
\text { Card Expenditures }\end{array}$ \\
\hline 2006 & $\$ 16,272$ & $\$ 8,754$ & $53.8 \%$ & $\$ 3,669$ & $22.5 \%$ \\
\hline 2007 & $\$ 27,595$ & $\$ 10,080$ & $36.5 \%$ & $\$ 10,873$ & $39.4 \%$ \\
\hline 2008 & $\$ 25,790$ & $\$ 15,011$ & $58.2 \%$ & $\$ 4,324$ & $27.1 \%$ \\
\hline Total & $\$ 69,657$ & $\$ 33,845$ & $48.6 \%$ & $\$ 18,866$ & $27.1 \%$ \\
\hline
\end{tabular}

Table 8: Examples of Unsupported or Questionable Credit Card Transactions Director of Planning and Development John Slone

\begin{tabular}{|l|l|}
\hline Walmart.com- Wii games, Wii Console & $\$ 663$ \\
\hline Dick's Sporting Goods - Shirts & $\$ 636$ \\
\hline Francis H I'I Brown - Golf Fees \& Rental clubs & $\$ 480$ \\
\hline Evan's Firearms \& Archery - Shotgun & $\$ 476$ \\
\hline Dick's Sporting Goods - Clay Targets, shotgun cleaning kit, shells & $\$ 282$ \\
\hline Sportsman Warehouse - Ammunition & $\$ 230$ \\
\hline Allsports - Cincinnati Bengals \& Pittsburg Steelers Jackets & $\$ 121$ \\
\hline Kmart - Vest, Dove \& Quail, Gun case, Shell Bag & $\$ 101$ \\
\hline
\end{tabular}

Table 9: Summary Analysis - Director of Planning and Development John Slone's Credit Card Transactions

\begin{tabular}{|c|c|c|c|c|c|}
\hline Year & $\begin{array}{c}\text { Total Credit Card } \\
\text { Expenditures }\end{array}$ & $\begin{array}{c}\text { Inadequate } \\
\text { Documentation or } \\
\text { Questionable Business } \\
\text { Purpose }\end{array}$ & $\begin{array}{c}\text { Percent of Credit } \\
\text { Card Expenditures }\end{array}$ & $\begin{array}{c}\text { No Supporting } \\
\text { Documentation }\end{array}$ & $\begin{array}{c}\text { Percent of Credit } \\
\text { Card Expenditures }\end{array}$ \\
\hline 2006 & $\$ 17,607$ & $\$ 7,705$ & $43.8 \%$ & $\$ 1,248$ & $7.1 \%$ \\
\hline 2007 & $\$ 10,338$ & $\$ 6,672$ & $64.5 \%$ & $\$ 80$ & $.77 \%$ \\
\hline 2008 & $\$ 13,504$ & $\$ 4,194$ & $31.1 \%$ & $\$ 122$ & $.9 \%$ \\
\hline Total & $\$ 41,449$ & $\$ 18,571$ & $44.8 \%$ & $\$ 1,450$ & $3.5 \%$ \\
\hline
\end{tabular}

Table 10: Examples of Unsupported or Questionable Credit Card Transactions - Other Employees of the Airport

\begin{tabular}{|l|c|}
\hline \multicolumn{1}{|c|}{ Vendor Name } & Transaction Amount \\
\hline $\begin{array}{l}\text { Godiva Chocolatier - Candy } \\
\text { 4 Different Purchases }\end{array}$ & $\$ 2,949$ \\
\hline $\begin{array}{l}\text { GQ Limousine Service - Limo Service to Attend the Legally Blonde Play \& NY } \\
\text { Yankees Game }\end{array}$ & $\$ 1,962$ \\
\hline Stubhub - 4 Tickets for Atlanta Hawks Game & $\$ 1,437$ \\
\hline Liquor Barn - 7 Different Purchases & $\$ 1,031$ \\
\hline Palace Theatre - Tickets to Legally Blonde Play & $\$ 972$ \\
\hline Cigar Oasis - Six Cigar Humidifiers & $\$ 847$ \\
\hline Per Order of Executive Director & $\$ 792$ \\
\hline Lexington Legends- Bob Dylan Concert & $\$ 729$ \\
\hline Stubhub- Hannah Montana Tickets & $\$ 720$ \\
Per Executive Director & $\$ 703$ \\
\hline Tickets Now - Hannah Montana Tickets & $\$ 663$ \\
\hline Walmart.com- Wii System & $\$ 636$ \\
\hline Dick's Sporting Goods - 26 Polo Shirts & $\$ 469$ \\
\hline NA'ALAP Horse Stables & $\$ 402$ \\
\hline Lexington Legends - Hank Williams Concert & $\$ 438$ \\
\hline 877 Spirits - Liquor & $\$ 410$ \\
\hline Malone's Restaurant & $\$ 390$ \\
\hline Rochester Big \& Tall - Golf Shirts & $\$ 325$ \\
\hline Man O War Golf - 4 Golf Lessons & $\$ 315$ \\
\hline The Village Vineyard - Liquor & $\$ 230$ \\
\hline Rebecca Ruth - Candy & $\$ 211$ \\
\hline Kroger Grocery Store - No Documentation & \\
\hline
\end{tabular}


The State Auditor's investigation also revealed that no policy existed for an employee to anonymously report areas of concern to the board. The ACFE states that $40.2 \%$ of frauds are uncovered because of anonymous tips (ACFE, 2010). The state auditors found that board meeting minutes lacked detail and provided no discussion of executive travel expenses, expense reimbursements, or other membership and benefit fees. In a most disturbing finding, it was noted that in the Fall of 2005, financial records, including credit card statements and expense reports, were removed from the airport accounting office and never returned. Such a finding should again be a red flag for the auditors if they actively looking for red flags.

\section{OUTCOMES OF THE FRAUD}

\section{Judicial Outcome}

Michael Gobb pleaded guilty to two counts of felony deception. The prosecution recommended five years in prison on each count. The judge sentenced Gobb to five years on each count but ordered probation instead of prison. Under the terms of the probation, Gobb had to undergo random drug and alcohol testing and complete 500 hours of community service. Gobb also paid restitution of over $\$ 55,000$. He completely escaped jail time (Hewlett, 2010b).

Airport Director of Administration and Finance, John Rhodes, pleaded guilty to one count of felony theft by deception. Rhodes was sentenced to $2^{1 / 2}$ years in prison but was conditionally discharged for five years. The prosecutor had recommended that Rhodes serve five years in prison. By being conditionally discharged, Rhodes would serve no prison time as long as he stayed out of trouble with the law. Rhodes had previously reimbursed the airport \$5,000 for "unauthorized reimbursements" prior to his indictment (Hewlett and Alessi, 2009).

Both John Coon, Director of Operations, and John Slone, Director of Planning and Development, accepted plea deals that amended their felony charges to misdemeanor charges of conspiracy to commit theft by deception and that levied penalties of up to 12 months in jail and $\$ 500$ fines. The judge sentenced them to 12 months in jail but conditionally discharged them for two years. Slone repaid the airport $\$ 2,300$, and Coon repaid the airport approximately $\$ 1,100$ (Hewlett, 2010a).

None of the main perpetrators in the Blue Grass Airport case received jail time. The prosecuting attorney disagreed with the judge's recommendations. The prosecutor stated, "The public believes crime pays. In many parts of our society, people believe that white-collar criminals receive rich man's justice and seldom go to prison." (Hewlett, 2010b)

\section{Airport Policy Changes}

In the aftermath of the airport fraud, the airport board implemented several policy changes to prevent excessive and fraudulent spending. The first change did away with all credit cards that were paid for by the airport. The Board set strict limits on meal reimbursements with a maximum amount of $\$ 50$ for dinner, $\$ 30$ for lunch, and $\$ 25$ for breakfast. The Board also established guidelines on airfare and rental car costs, lodging costs, and allowable entertainment expenses (Commonwealth of Kentucky Auditor of Public Accounts, 2009, pp.199-256).

The Board required that any expenditure by the Executive Director be pre-approved by the Board's Chairman. The Board adopted a new whistleblower policy to protect airport workers and vendors who blow the whistle on wrongdoing. The Board hired a new external auditing firm, replacing Potter and Co. which had served as the external auditor for 20 years. The Board also elected a new chairman.

The new Board policy renamed the Finance Committee to the Finance and Audit Committee. This committee was charged with reviewing each month's actual expenditures against budget for all categories of employee travel and other business expense reimbursement. The policy restricted expenditures for entertainment or gifts for tenants, customers, and business partners without the advance written approval of the Board's Chairman. 
The Board did not think it would be cost effective to hire a full-time internal auditor. However, the Board stated that they plan to engage their external auditing firm to assess and issue a report on the effectiveness of the airport's internal controls. This examination of internal controls will be more comprehensive than the assessment of internal controls during a normal audit and will allow the auditors to find deficiencies and make recommendations to improve controls. Auditors generally make recommendations regarding further strengthening those internal controls.

\section{CONCLUSIONS}

The fraud at the Bluegrass Airport was not complex. The fact that the control environment and control activities were almost nonexistent allowed top management and other employees to charge both personal expenditures and highly questionable business expenditures to the airport. At the fraud's core was a lack of ethical values by the airport's executives and a lack of oversight by the airport's Board.

There was no review process in place to ensure that potential wrongdoing would be detected. No employee or Board member was reviewing expense reimbursements for legitimacy. The airport board did not provide the requisite oversight to ensure that expenditures were for only reasonable business purposes. The external auditing firm did not detect the fraud, nor did they appear to question that actual expenditures on training and travel significantly exceeded budgeted amounts. If the firm did detect these large variances, they allowed management to "explain away" any concerns the auditors had.

The Blue Grass Airport fraud shows the importance of an entity's control environment and control procedures. The case also shows the importance and the consequences of lack of integrity and ethical values. It shows what happens when the board of directors fails to meet its fiduciary oversight responsibilities. The case also demonstrates that simple controls, such as reviewing expense accounts, comparing budgeted amounts to actual amounts, and controls over access to company credit cards, can prevent or detect unauthorized expenditures and save organizations large sums of money.

\section{AUTHOR INFORMATION}

Thomas G. Noland Ph.D., CPA, CMA, CDFM is a Professor of Accounting in the Mitchell College of Business at the University of South Alabama. Dr. Noland has previously held positions with the Federal Deposit Insurance Corporation and the Securities \& Exchange Commission. E-mail: tnoland@usouthal.edu (Corresponding author)

Eddie Metrejean Ph.D., CPA, CFE is an Associate Professor of Accountancy at Georgia Southern University. Dr. Metrejean previously served as an auditor with a large regional public accounting firm and then as a corporate controller for a group of small companies. E-mail: emetrejean@georgiasouthern.edu

\section{REFERENCES}

1. American Institute of Certified Public Accountants (1988). Statements on Auditing Standards No. 56, Analytical Procedures. New York, NY: AICPA.

2. American Institute of Certified Public Accountants (2002). Statements on Auditing Standards No. 99, Consideration of Fraud in a Financial Statement Audit. New York, NY: AICPA.

3. Association of Certified Fraud Examiners (2010). Report to the Nations on Occupational Fraud and Abuse. Austin, TX: ACFE.

4. Committee of Sponsoring Organizations. (1992). Internal Control Integrated Framework.

5. Commonwealth of Kentucky Auditor of Public Accounts (2009). "Examination of Certain Financial Transactions, Policies, and Procedures of the Lexington Blue Grass Airport" February 25, 2009.

6. Hewlett, Jennifer (2008a). “A sky-high expense account.” Lexington Herald Leader, November 23, 2008.

7. Hewlett, Jennifer (2009). "Airport board makes expense and ethics changes." Lexington Herald Leader, February 26, 2009.

8. Hewlett, Jennifer (2010a). "No jail time for 2 more ex-executives." Lexington Herald Leader, June 26, 2010. 
9. Hewlett, Jennifer (2010b). "Ex-airport chief Gobb gets probation.” Lexington Herald Leader, August 14, 2010.

10. Hewlett, J., and Alessi, R. (2009). "Luallen describes possible criminal activity in release of airport audit." Lexington Herald Leader, February 26, 2009. 
NOTES 